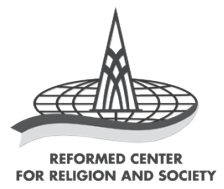

Societas Dei: Jurnal Agama dan Masyarakat Vol. 08, No. 1 (April 2021): 85-107 http://societasdei.rcrs.org/index.php/SD/issue/archive

p-ISSN: 2407-0556; e-ISSN: 2599-3267

DOI: $10.33550 /$ sd.v8i1.209

Received: 19 January 2021

Revised: 16 February 2021

Accepted: 30 March 2021

\title{
PEMBATASAN KEBEBASAN BERAGAMA DAN BERKEYAKINAN DI INDONESIA SERTA IMPLIKASINYA
}

\section{LIMITATION THE RELIGION AND BELIEF FREEDOM IN INDONESIA AND THEIR IMPLICATIONS}

\author{
Rohit Mahatir Manese \\ Program Studi Interdisiplinary Islamic Studies \\ Pascasarjana UIN Sunan Kalijaga, Yogyakarta \\ rohit@iain-manado.ac.id
}




\title{
Abstract:
}

This article aims to describe caused the restriction of religion and belief freedom and its implications in Indonesia. The author's argument on the ownership that limitation of the religion and belief freedom in Indonesia which have mainstreams about religious values and blasphemy. It causes diversity in Indonesia to limited pluralism experience. With the perspective of pluralism, limiting the religion and belief freedom is carried out by the state makes ancestral religions which is not declared as official religions. Apart from making the state that recognizes only six religions, this statement contradicts the Universal Declaration of Human Rights (UDHR) and the International Covenant. By using the literature review method, this article finds that the religion and belief freedom in Indonesia experiences delimited pluralism so this condition brings to negotiated on ancestral religions and intolerance to minority groups.

Keywords: Freedom of Religion and Belief; Religious Value; Delimited Pluralism; Discrimination; Intolerance.

\begin{abstract}
Abstrak:
Artikel ini bertujuan untuk mengurai penyebab pembatasan kebebasan beragama dan berkeyakinan (KBB) serta implikasinya di Indonesia. Penulis berargumen bahwa pembatasan terhadap KBB di Indonesia, yang mengarusutamakan nilai-nilai agama dan penodaan agama, membuat keragaman di Indonesia mengalami pluralisme terbatas. Dengan kacamata pluralisme terbatas, pembatasan $\mathrm{KBB}$ yang dilakukan oleh negara membuat agama-agama leluhur tidak diakui sebagai agama resmi. Selain membuat negara hanya mengakui enam agama, pembatasan itu bertolak belakang dengan Deklarasi Universal Hak Asasi Manusia (DUHAM) dan Kovenan Internasional. Dengan menggunakan metode literature review artikel ini menemukan bahwa KBB di Indonesia mengalami pluralisme terbatas (delimited pluralism) sehingga kondisi ini menimbulkan diskriminasi pada agama leluhur dan intoleransi pada kelompok minoritas.
\end{abstract}

Kata-kata kunci: Kebebasan Beragama dan Berkeyakinan; Pluralisme Terbatas; Diskriminasi; Intoleransi. 


\section{Pendahuluan}

Kebebasan beragama dan berkeyakinan (KBB) merupakan sebuah realitas kehidupan di mana setiap individu bebas memilih agama dan keyakinan yang dipercayai serta dipraktikkannya. KBB berperan penting untuk mengangkat dan menghormati martabat manusia serta berupaya untuk menciptakan kehidupan yang harmonis.

Di Indonesia sendiri KBB mulai mendapat perhatian ketika memasuki era Reformasi., akan tetapi KBB di Indonesia masih mengalami permasalahan. Hal itu ditunjukkan dengan beberapa fakta pelanggaran KBB di Indonesia, di antaranya adalah: pelarangan ibadah Gereja Pantekosta di Indonesia (GPdI) Sumedang pada tahun 2012; pencabutan izin IMB oleh pemerintah terhadap Gereja Kristen Indonesia (GKI) Yasmin, Bogor; pembakaran tempat ibadah Sapta Dharma di Rembang oleh sekelompok orang; pelarangan ibadah terhadap Jemaat Ahmadiyah Indonesia (JAI) di Subang disertai dengan tindakan kekerasan; perusakan masjid Al-Kautsar milik JAI Kendal yang terjadi pada 22-23 Mei 2016. ${ }^{1}$ Hal ini sejalan dengan temuan Wahid Institute pada tahun 2015 yang menunjukkan terjadi pelanggaran KBB di beberapa kota di Indonesia. Jawa Barat dan Aceh menjadi provinsi tertinggi kasus pelanggaran KBB. Terjadi 46 peristiwa di Jawa Barat, Aceh sebanyak 36 peristiwa disusul kemudian oleh DKI Jakarta dengan 23 peristiwa, Yogyakarta sejumlah 10 peristiwa. $^{2}$

Faktor-faktor yang melatarbelakangi pelanggaran di antaranya adalah kemunculan kelompok intoleran yang sering melakukan penertiban rumah ibadah dan pemberantasan aliran kepercayaan yang dianggap sesat. Faktor lainnya adalah maraknya ujaran kebencian terhadap identitas agama. ${ }^{3}$ Kasus demi kasus di atas menunjukkan masih maraknya pelanggaran terhadap KBB di Indonesia.

Realitas tersebut juga mendapat perhatian yang menghasilkan beberapa penelitian. Penelitian dari Delmus Puneri Salim berfokus pada pengelolaan relasi antaragama di Indonesia. ${ }^{4}$ Penemuan tersebut menemukan bahwa pengelolaan agama di Indonesia dirumuskan dengan konsep kerukunan antarumat beragama. Hal ini dibuat untuk mencegah konflik, dan sering dipahami sebagai bagian dari kebebasan beragama. Menurut

Lutfy M. Marizal, “Ini 11 Kasus Pelanggaran Kebebasan Beragama Berkeyakinan 3 Bulan Terakhir,” Kompas, 1 Juli 2016, diakses 24 Februari 2021, https://nasional.kompas.com/read/2016/07/01/05050071/ Ini.11.Kasus.Pelanggaran.Kebebasan.Beragama.atau.Berkeyakinan.3.Bulan.Terakhir?page=all.

Alamsayah Djafar dkk, "Laporan Tahunan Kemerdekaan Beragama dan Berkeyakinan (KBB) di Indonesia, Utang Warisan Tak Kunjung Terlunasi," The WAHID Institute (2015), 33.

Ibid., 47.

Delmus Puneri Salim, "Kerukunan Umat Beragama Vs Kebebasan Beragama di Indonesia," Jurnal Potret Pemikiran 21, no. 2, (Juli -Desember 2017): 15-35, diakses 21 Desember 2020, http://dx.doi. org/10.30984/pp.v21i2.741. 


\section{ROHIT MAHATIR MANESE}

penulis alih-alih mengikuti kebebasan beragama yang telah dideklarasikan oleh DUHAM justru konsep kerukunan hidup beragama jauh berbeda bahkan kontradiktif dengan kebebasan beragama. Penelitian ini hanya mengulas tentang kontradiksi antara kerukunan umat beragama dengan KBB, akan tetapi tidak melihat aturan yang ada di belakangnya seperti nilainilai agama serta penodaan dan pencegahan dalam penyalahgunaan agama. Penelitian ini juga tidak mengulas implikasi dari pertentangan antara KBB dan kerukunan umat beragama.

Penelitian lainnya dilakukan oleh Iqbal Hasanudin yang berfokus pada landasan filosofis terhadap hak warga negara untuk KBB. ${ }^{5}$ Penelitian ini menemukan KBB masih berada pada tataran politis dan belum memiliki dasar etis-filosofis. Hal ini menyebabkan masalah di dalam KBB seperti penghargaan dan perlindungan terhadap KBB, forum internum (forum internal), dan forum externum (forum eksternal). ${ }^{6}$ Untuk menjawab masalah tersebut secara filosofis Iqbal menggunakan konsep dari Robert Nozick yakni teori keadilan dan pemikiran John Rawls yakni teori kebebasan libertarian. Dalam perspektif Robert Nozick, Iqbal melihat bahwa perlindungan terhadap KBB merupakan wujud dari perlindungan dan penghargaan terhadap hak manusia sebagai individu yang bebas, egaliter, dan rasional satu sama lain. Sementara melalui perspektif Rawls, Iqbal memberikan dasar yang kokoh atas pembelaan terhadap KBB. Dari hasil kacamata teori-teori tersebut penelitian ini menemukan bahwa KBB pada forum internal tidak dapat dilakukan pembatasan oleh siapa pun, sementara pembatasan terhadap KBB boleh berlaku pada forum eksternal. Penelitian ini menyetujui pembatasan KBB pada ranah eksternal, akan tetapi Iqbal tidak menjelaskan alasan secara legal-etis kenapa KBB boleh dibatasi. Selanjutnya penelitian ini juga tidak membahas pembatasan terhadap KBB yang terjadi di Indonesia.

Penelitian selanjutnya diulas oleh Victoria H. Situmorang yang berfokus pada pelanggaran KBB di Indonesia. ${ }^{7}$ Penelitian ini menemukan bahwa pelanggaran terhadap KBB disebabkan oleh keterlambatan pemerintah. Keterlambatan ini dikarenakan tidak ada langkah dalam pencegahan

Iqbal Hasanuddin, “Hak atas Kebebasan Beragama/Berkeyakinan: Sebuah Upaya Pendasaran Filosofis, Societas Dei: Jurnal Agama dan Masyarakat 4, no. 1, (April 2017): 96-12, diakses 15 Februari 2021, http://doi.org/10.33550/sd.v4i1.44.

Forum Internum, adalah hak yang berada dalam pikiran atau kesadaran seseorang. Hak ini mencakup kebebasan setiap orang untuk memiliki, menganut, mempertahankan atau pindah agama/ keyakinan. Sementara Forum Exsternum adalah hak yang termanifestasi keluar, baik dalam sikap dan tindakan seseorang. Hal ini mencakup kebebasan setiap orang, baik sendiri maupun bersama-sama dengan orang lain, di tempat umum atau wilayah pribadi, untuk memanifestasikan agama atau kepercayaannya di dalam pengajaran, pengalaman, ibadah dan penataannya.

Victoria H. Situmorang, "Kebebasan Beragama Sebagai Bagian dari Hak Asasi Manusia," Jurnal HAM 10, no. 1, (Juli 2019): 57-67, diakses 13 Januari 2021, http://dx.doi.org/10.30641/ham.2019.10.57-67. 
konflik. Pemerintah baru hadir setelah terjadinya pelanggaran KBB di tengah masyarakat. Selanjutnya penelitian ini menemukan lemahnya hukum di Indonesia untuk menumpas pelanggaran KBB. Namun, penelitian ini hanya melihat penerapan KBB tanpa lebih jauh melihat dasar permasalahannya, yaitu pembatasan yang dilakukan oleh negara terhadap KBB itu sendiri sehingga kesimpulan yang diperoleh dalam penelitian ini hanya bertumpu pada saat pelanggaran KBB itu terjadi.

Penelitian berikutnya ditulis oleh Faiq Tobroni yang berfokus pada penalaran hakim dalam membedakan antara kebebasan beragama dan penodaan agama serta kaitannya dengan HAM. Penelitian ini mengambil kasus pidana putusan Pengadilan Negeri no 69 tahun 2012 yang dialami oleh TM. TM dipidana atas tuduhan menodai agama. Tuduhan itu terjadi karena sebelumnya TM dilaporkan telah melakukan tindakan penodaan agama, diantaranya adalah: TM mengatakan al-Qur'an selama ini palsu; menambahkan bunyi dalam syahadat; dan mengubah rukun iman dan rukun Islam. Penelitian ini menemukan bahwa penalaran hakim atas kasus TM, tidak semuanya masuk dalam penodaan agama. Kasus yang masuk dalam penodaan agama adalah perkataaan TM bahwa Al-Qur'an adalah palsu sedangkan rekonstruksi TM terhadap rukun Islam dan rukun iman merupakan bagian dari KBB. Penelitian ini hanya mengulas tentang satu masalah dalam KBB, tetapi tidak mengulas kenapa masalah ini dapat masuk dalam kategori pelanggaran terhadap KBB. Selanjutnya penelitian ini hanya berfokus pada penerapan KBB itu sendiri, tetapi tidak melihat lebih jauh masalah KBB dengan kebijakan penodaan agama di Indonesia.

Penelitian yang saat ini penulis lakukan tentunya memperkaya penelitian-penelitian sebelumnya mengenai KBB di Indonesia. Namun fokus serta titik perbedaannya adalah penelitian ini akan mengurai alasan di balik pembatasan KBB yang menimbulkan segala pelanggaran terhadap KBB terjadi di Indonesia. Bagian lain dalam artikel ini adalah mengulas implikasi setelah pembatasan KBB di Indonesia.

Tesis penulis adalah pembatasan KBB yang mengarusutamakan nilai-nilai agama dan penodaan agama membuat keragaman di Indonesia mengalami pluralisme terbatas. Dengan kacamata pluralisme terbatas pembatasan KBB yang dilakukan oleh negara membuat agama-agama leluhur tidak diakui sebagai agama resmi. Jikalau mereka ingin diakui oleh negara maka mereka harus mengikuti nilai-nilai agama dan definisi agama resmi. Dalam aras sosial kondisi ini menimbulkan diskriminasi dan intoleransi dalam kehidupan keagamaan di Indonesia. 


\section{Metode Penelitian}

Penelitian ini menggunakan metode penelitian literature review atau tinjauan pustaka. Literature review merupakan metode yang mengkaji dan menelaah temuan dalam kepustakaan seperti buku, jurnal ilmiah, artikel, dan majalah sedangkan pendekatan yang digunakan adalah pendekatan kualitatif. Pendekatan kualitatif memberikan informasi berupa kata-kata atau teks untuk dianalisis sehingga memperoleh deskripsi. ${ }^{8}$ Adapun langkah-langkah yang dilakukan penulis dalam penelitian ini, di antaranya adalah: pertama, memilih topik yang sesuai dengan minat atau isu penulis; kedua, mencari literatur yang relevan dengan topik penelitian; ketiga mendapatkan gambaran dari topik penelitian; keempat, membuat catatan mengenai temuan pada penelitian sebelumnya, kelima, penulis membuat sintesis antara penelitian sebelumnya dengan penelitian ini. Dengan mengikuti langkah-langkah tersebut penulis dapat memperoleh hasil penelitian tentang pembatasan KBB di Indonesia.

Sesuai permasalahan yang akan menjadi fokus pada penelitian ini, penulis menuangkan dalam beberapa bagian pembahasan. Pertama, penulis mengeksplorasi diskursus KBB yang ada dalam DUHAM, ICCPR, maupun norma-norma dari KBB. Kedua, kebijakan KBB di Indonesia. Ketiga, pembatasan KBB di Indonesia. Keempat, implikasi dari pembatasan terhadap KBB di Indonesia.

\section{KBB di Lingkup Internasional}

KBB terdapat dalam dokumen DUHAM tahun 1948. Dokumen ini telah diterima dan dideklarasikan oleh Majelis PBB pada tanggal 10 Desember 1948. Deklarasi ini merupakan standar umum bagi semua bangsa dan negara agar menghargai hak-hak dan kebebasan manusia termasuk KBB. Dalam DUHAM penjelasan mengenai KBB termaktub pada pasal 18. ${ }^{9}$ Pasal tersebut berbunyi:

Setiap orang berhak atas kemerdekaan berpikir, berkeyakinan, dan beragama. Hak ini mencakup kebebasan untuk berganti agama atau kepercayaan; kebebasan untuk menjalankan agama atau kepercayaannya dalam kegiatan pengajaran, peribadatan, pemujaan dan ketaatan. Hal itu dilakukan baik secara sendiri maupun secara kolektif di tempat khusus atau di tempat terbuka.

\footnotetext{
Majelis Umum PBB, Deklarasi Universal Hak-Hak Asasi Manusia, diterima dan diumumkan oleh majelis Umum melalui resolusi 217 A (III) Paris: 217 A, 1948, 1-6, diakses 2 April 2021, https://www. komnasham.go.id/files/1475231326-deklarasi-universal-hak-asasi--\$R48R63.pdf.
} 2010), 7.

J.R Raco, Metode Penelitian Kualitatif Jenis, Karakteristik, dan Keunggulannya (Jakarta, Grasindo, 
KBB juga semakin diperkuat dengan International Covenant on Civil and Political Rights (ICCPR) yang lahir pada tahun 1966. Pada pasal 18, ICCPR menyebutkan bahwa:

(1) Setiap orang berhak atas kebebasan berpikir, keyakinan dan beragama. Hak ini mencakup kebebasan untuk menetapkan agama atau kepercayaan atas pilihannya sendiri, dan kebebasan, baik sendiri maupun bersama-sama dengan orang lain, baik di tempat umum atau tertutup, untuk menjalankan agama dan kepercayaannya dalam kegiatan ibadah, penataan, pengamalan dan pengajaran;

(2) Tidak seorang pun dapat dipaksa sehingga terganggu kebebasannya untuk menganut atau menetapkan agama atau kepercayaannya sesuai dengan pilihannya;

(3) Kebebasan menjalankan dan menentukan agama atau kepercayaan seseorang hanya dapat dibatasi oleh ketentuan berdasarkan hukum, dan yang diperlukan untuk melindungi keamanan, ketertiban, kesehatan, atau moral masyarakat, atau hak-hak dan kebebasan dasar orang lain;

(4) Pihak-pihak dalam kovenan ini berjanji untuk menghormati kebebasan orang tua, dan apabila diakui, wali hukum yang sah untuk memastikan bahwa pendidikan agama dan moral bagi anak-anak mereka sesuai dengan keyakinan mereka sendiri. ${ }^{10}$

Selanjutnya dijelaskan juga pada ICCPR pasal 20 ayat 2 tentang KBB, ayat ini berbunyi, "Segala tindakan yang menganjurkan kebencian atas dasar kebangsaan, ras atau agama yang merupakan hasutan untuk melakukan diskriminasi, permusuhan atau kekerasan, harus dilarang oleh hukum"11 Beberapa tahun kemudian tepatnya pada tahun 1981 diadakan konsensus yang melahirkan Declaration on the elimination of All Forms of Intolerance and Discrimination Based Religion or Belief. Konsensus-konsensus itu menjadi dasar bagi negara-negara di dunia untuk memperhatikan KBB terhadap warga negara.

Menurut DUHAM dan beberapa kovenan internasional terdapat norma-norma yang harus diikuti ketika suatu negara atau masyarakat internasional ingin menerapkan $\mathrm{KBB}$, antara lain:

1. Kebebasan internal. Berdasarkan norma ini, setiap orang dipandang memiliki hak kebebasan berpikir, berkesadaran, dan beragama. Norma ini juga mengakui kebebasan setiap orang untuk mempertahankan agama, atau bahkan mengubah agama serta kepercayaannya.

10 Republik Indonesia, Undang-Undang Republik Indonesia Nomor 12 Tahun 2005 Tentang Pengesahan Internartional Covenant On Civil And Political Rights: Kovenan Internasional Tentang Hak-Hak Sipil dan Politik, Lembaran Negara Republik Indonesia nomor 119, Jakarta, Pemerintah Republik Indonesia, 2005, diakses 20 Maret 2021, https://www.dpr.go.id/doksetjen/dokumen/-Regulasi-UU-No.-12-Tahun-2005-TentangPengesahan-Kovenan-Internasional-Tentang-Hak-Hak-Sipil-dan-Politik-1552380410.pdf.

11 Ibid. 


\section{ROHIT MAHATIR MANESE}

2. Kebebasan eksternal. Norma ini mengakui kebebasan beragama atau keyakinan dalam berbagai wujud manifestasinya, seperti kebebasan dalam pengajaran, peribadatan, serta ketaatan dalam beragama. Manifestasi dari norma ini adalah kebebasan beragama dan berkepercayaan dapat dilaksanakan baik di ranah pribadi maupun publik.

3. Tanpa paksaan. Norma ini menekankan kemerdekaan individu dari segala bentuk paksaan dalam mengadopsi suatu agama atau berkepercayaan. Dengan kata lain, setiap individu memiliki kebebasan dan menjalankan agama atau kepercayaannya tanpa perlu dipaksa oleh siapa pun.

4. Tanpa diskriminasi. Berdasarkan norma ini, seluruh individu yang berada di dalam kekuasaan negara harus dihargai dan dipastikan oleh negara terjamin kebebasan beragama dan kepercayaan mereka tanpa memandang jenis kelamin, bahasa, pandangan politik, asal-usul bangsa, status kelahiran, agama maupun kepercayaannya.

5. Hak dari orang tua dan wali. Menurut norma ini, orang tua dan wali yang secara hukum absah bebas untuk memastikan pengajaran, pendidikan agama, dan keyakinan bagi anak-anaknya. Negara harus menghargai dan menjamin hak-hak orang tua atau wali tersebut.

6. Kebebasan berasosiasi, berkomunitas, berkumpul, dan memperoleh akses terhadap status hukum. Komunitas keagamaan mempunyai hak untuk mengorganisasikan diri mereka dan negara wajib untuk melindunginya sesuai hukum yang berlaku.

7. Pembatasan yang diperkenankan terhadap kebebasan eksternal. Kebebasan untuk mewujudkan atau mengeskpresikan agama dan kepercayaan dapat dikenai pembatasan oleh hukum dengan alasan ingin melindungi keselamatan umum, ketertiban, kesehatan dan moral dan hak-hak dasar lainnya.

8. Negara tidak boleh mengurangi hak kebebasan beragama atau berkepercayaan bahkan dalam situasi apapun. ${ }^{12}$

\section{Kebijakan KBB di Indonesia}

Kebijakan KBB di Indonesia sejak awal termuat pada UUD 1945 pasal 29. Dalam kebijakan tersebut negara dengan sangat jelas menjamin kemerdekaan beragama bagi para penduduknya. Sejak kemerdekaan, KBB sudah mendapat tempat di Indonesia, akan tetapi belum secara resmi

12 Lidhlom Tore, "Philosophical and Religious Justifications of Freedom of Religion or Belief," in Facilitating Freedom of Religion or Belief: A Deskbook, ed. Tore Lindholm, W. Cole Durham, Jr., Bahia G. Tahzib-Lie (Springer, 2004), 19-61. 
diletakkan sebagai bagian dari HAM. KBB dimasukkan sebagai konsep dan HAM secara resmi terjadi pada era Reformasi. Pada era ini negara melakukan amandemen Undang-Undang Dasar dan memasukkan satu bab tambahan tentang HAM pada pasal 28A-28J. Dalam pasal-pasal tersebut jaminan negara terhadap KBB dimuat dalam UUD pasal 28 E dan 28 I. ${ }^{13}$ Pada pasal $28 \mathrm{E}$ ayat 1 berbunyi: "Setiap orang bebas memeluk agama dan beribadat menurut agamanya, memilih pendidikan dan pengajaran, memilih pekerjaan, memilih kewarganegaraan, memilih tempat tinggal di wilayah negara dan meninggalkannya, serta berhak kembali“ Selanjutnya pada pasal 28 I menyebutkan bahwa:

(1) Hak untuk hidup, hak untuk tidak disiksa, hak kemerdekaan pikiran dan hati nurani, hak beragama, hak untuk tidak diperbudak, hak untuk diakui sebagai pribadi di hadapan hukum, dan hak untuk tidak dituntut atas dasar hukum yang berlaku surut adalah hak asasi manusia yang tidak dapat dikurangi dalam keadaan apa pun;

(2) Setiap orang berhak bebas atas perlakuan yang bersifat diskriminatif atas dasar apa pun dan berhak mendapatkan perlindungan terhadap perlakuan yang bersifat diskriminatif itu.

Pasal 28 E menjamin warga negara untuk berhak meyakini, mengekspresikan, dan menjalankan agama yang dipilihnya. Sementara pada pasal 28 I menjelaskan bahwa setiap warga negara mempunyai hak untuk hidup, bebas berpikir, bernurani, beragama serta ada jaminan untuk dilindungi oleh hukum dan tidak diperbudak. Pasal ini juga menjelaskan bahwa hakhak tersebut merupakan hak yang tidak dapat dibelenggu oleh negara dalam situasi dan kondisi apapun. Indonesia juga memasukkan KBB pada kebijakan yang lain di antaranya adalah: Undang-Undang (UU) No. 39 Tahun 1999 tentang Hak Asasi Manusia. Pada pasal empat dijelaskan bahwa setiap orang atau warga negara mempunyai hak untuk memeluk agamanya dan menjalankan ritual menurut agamanya masing-masing. Hal ini terdapat dalam ratifikasi terhadap ICCPR dalam UU no. 12 tahun 2005 tentang Pengesahan International Covenant on Civil and Political Rights (Kovenan Internasional tentang Hak-Hak Sipil dan Politik).

Klausul-klausul terhadap KBB juga bermunculan dalam kebijakan yang lain, di antaranya adalah: UU No 7 Tahun 2012 tentang Penangangan Konflik Sosial yang mendorong adanya toleransi dan penghormatan terhadap KBB untuk menjaga perdamaian; UU No 24 tahun 2007 tentang Penanggulangan Bencana yang menjelaskan tentang pelarangan diskriminasi yang didasarkan atas nama agama dalam hal penyantunan bantuan korban bencana; serta

\footnotetext{
13 Republik Indonesia, Undang-Undang Dasar Negara Republik Indonesia Tahun 1945, pasal 28, (Jakarta: Pemerintah Republik Indonesia, 2002), diakses 2 April 2002, https://luk.staff.ugm.ac.id/atur/UUD1945.pdf.
} 
Peraturan Kapolri terkait dengan prinsip-prinsip dan standar hak asasi manusia dalam menjalankan tugas kepolisian. ${ }^{14}$

Langkah Indonesia terhadap kebijakan KBB sangat tepat dan progresif karena KBB sesuai dengan kondisi Indonesia yang plural dan sejalan dengan demokrasi sebagai sistem politik. Selain mengadopsi konsensus internasional, agenda merumuskan kebijakan KBB di Indonesia merupakan kebijakan yang sangat relevan untuk mengatur keberagaman agama di Indonesia karena agama di Indonesia berpengaruh dan hingga sekarang ini memainkan peran penting dalam hajat hidup berbangsa dan bernegara.

\section{Pembatasan KBB di Indonesia}

Pembatasan KBB utamanya mengikuti definisi dan nilai-nilai agama yang bersumber pada Undang-Undang No 1 PNPS tahun 1965 tentang Pencegahan Penodaan dan Penyalahgunaan Agama. Nilai-nilai agama berporos pada agama dominan yaitu agama yang diakui secara resmi. Definisi agama mengacu Departemen Agama pada tahun 1952 bahwa agama memiliki elemen-elemen tertentu, seperti nabi, kitab suci, dan pengakuan secara internasional. ${ }^{15}$ Agama-agama yang ada harus mengikuti aturan ini. Secara kebijakan, pembatasan KBB diatur dalam pasal 28 J UUD 1945 yang berbunyi:

(1) Setiap orang wajib menghormati hak asasi manusia orang lain dalam tertib kehidupan bermasyarakat, berbangsa, dan bernegara.

(2) Dalam menjalankan hak dan kebebasannya, setiap orang wajib tunduk kepada pembatasan yang ditetapkan dengan Undang-Undang dengan maksud semata-mata untuk menjamin pengakuan serta penghormatan atas hak dan kebebasan orang lain dan untuk memenuhi tuntutan yang adil sesuai dengan pertimbangan moral, nilai-nilai agama, keamanan, dan ketertiban umum dalam suatu masyarakat demokratis. ${ }^{16}$

Adapun pembatasan KBB di Indonesia karena mengikuti rumusan ICCPR yang mengatakan bahwa KBB boleh dibatasi terdapat pada pasal 18:

(3) Kebebasan untuk mengejawantahkan agama atau kepercayaan seseorang hanya dapat dibatasi oleh ketentuan berdasarkan hukum, dan apabila diperlukan untuk melindungi keamanan, ketertiban, kesehatan dan atau moral masyarakat, atau hak-hak dan kebebasan mendasar orang lain. ${ }^{17}$

14 Zainal Abidin Bagir Kajian tentang Kebebasan Beragama dan Berkeyakinan dan Implikasinya untuk Kebijakan, dalam Kebebasan , Toleransi dan Terorisme: Riset dan Kebijakan Agama di Indonesia, diedit oleh Ihsan Ali Fauzi dkk, (Jakarta: PUSAD, 2017), 61.

15 Ibid., 16.

16 Republik Indonesia, Undang-Undang Dasar Negara Republik Indonesia Tahun 1945.

17 Republik Indonesia, Undang-Undang Republik Indonesia Nomor 12 Tahun 2005 Tentang Pengesahan Internartional Covenant On Civil And Political Rights: Kovenan Internasional Tentang Hak-Hak Sipil dan Politik. 
Namun terdapat perbedaan antara pembatasan yang dibolehkan ICCPR dengan KBB yang telah diatur pada pasal 28 J UUD 1945. Seperti dijelaskan di atas, pembatasan KBB pada pasal $28 \mathrm{~J}$ memasukkan nilai-nilai agama, sementara pada ICCPR tidak terdapat nilai-nilai agama. Nilai-nilai agama yang dimaksud dalam pembatasan di Indonesia mengacu pada nilainilai agama resmi yang telah diakui oleh negara. Seperti dijelaskan di atas, pembatasan KBB di Indonesia terdapat pada pasal $28 \mathrm{~J}$ bahwa nilai-nilai agama menjadi pembatas HAM di Indonesia.

Selanjutnya kita juga tidak dapat memisahkan nilai-nilai agama dan definisi agama. Munculnya definisi agama membuat nilai-nilai agama secara tidak langsung berlaku, karena dua hal tersebut hanya terdapat pada agama yang diakui secara resmi dan menjadi agama dominan di Indonesia. Agama dominan ini adalah enam agama yang mendapat pengakuan secara langsung dari Indonesia. Pengakuan terhadap agama resmi dimuat pada UU No 1 Tahun 1965 tentang Pencegahan Penodaan dan Penyalahgunaan Agama. ${ }^{18}$ Fakta di atas menunjukkan bahwa pengelolaan KBB di Indonesia sangat bermasalah dengan dalih nilai-nilai agama sebagai moralitas publik dan sangat diperlukan untuk kepentingan umum. ${ }^{19}$ Padahal kondisi Indonesia sangat plural dan baru saja memasuki alam demokrasi yang memerlukan syarat kebebasan, pluralisme, dan egalitarianisme.

Bagi penulis ada tiga hal penting dalam pasal pembatasan di atas. Pertama, menunjukkan sikap paradoksal negara karena melindungi kebebasan namun di sisi lain membatasi kebebasan. Jikalau alasan negara melindungi warga negara, hal itu hanya berlaku pada warga negara yang terdaftar sebagai pemeluk agama resmi saja dan tidak bagi agama pemeluk agama leluhur. Kedua, menunjukkan kaburnya penafsiran antara moralitas dan nilai-nilai agama karena warga negara Indonesia menganggap agama adalah sumber moral tertinggi. Ketiga, menunjukkan perbedaan antara KBB yang menjadi konsensus internasional dan KBB yang diterapkan di Indonesia. Hal ini telah dijelaskan pada norma-norma KBB bahwa dalam situasi dan kondisi apapun negara tidak bisa melakukan pembelengguan atas KBB warga negara.

Dengan demikian warga negara harus mematuhi batasan-batasan yang ditentukan oleh kaburnya kebijakan tersebut dalam meyakini hingga menjalankan agama dan keyakinannya. Kebijakan-kebijakan tersebut hanya bertujuan untuk mengatur pengakuan negara dan penghormatan negara atas hak dan kebebasan orang lain serta pemenuhan untuk berbuat adil

\footnotetext{
18 Alamsyah Djafar, Intoleransi Memahami Kebencian Atas Nama Agama (Jakarta: Elex Media Komputindo, 2018), 224.

19 Bagir, Kajian tentang Kebebasan Beragama dan Berkeyakinan dan Implikasinya untuk Kebijakan, 61.
} 
berdasarkan pertimbangan moralitas dan nilai-nilai agama. ${ }^{20}$ Tetapi penghormatan dan pengaturan tersebut hanya tertuju kepada agama-agama yang diakui secara resmi saja.

\section{Pluralisme Terbatas}

Pembacaan terhadap fenomena pembatasan KBB, penulis merujuk pada konsep delimited pluralism atau pluralisme terbatas. Bagi Julia Howell pluralisme terbatas ini dipakai untuk membaca tiga komunitas agama di Indonesia, yaitu: Salamullah, Brahma Kumaris, dan Anand Ashram. Howell mengidentifikasi ketiganya sebagai gerakan keagamaan baru yang muncul sejak beberapa tahun terakhir di Indonesia, akan tetapi semenjak kelahirannya mereka harus menyesuaikan dengan hukum di Indonesia. Hal tersebut mengakibatkan mereka masih tidak dapat dikatakan sebagai agama. Padahal merujuk pada para penganutnya, ketiga gerakan tersebut adalah bagian dari agama. Tesis Howell menyatakan bahwa banyak tradisi agama dan identitas keagamaan yang inovatif di Indonesia didukung penuh dengan semangat advokasi, akan tetapi mereka telah dikeluarkan secara penuh oleh Undang-Undang dan kebijakan Departemen Agama sejak berdirinya bangsa ini. ${ }^{21}$

Sementara bagi Ahmad Najib Burhani pluralisme yang diadopsi di Indonesia adalah pluralisme terbatas. Hal ini bisa dilihat dari toleransi yang lebih banyak ditujukan kepada mereka yang masuk kategori enam agama yang diakui. Inilah yang mengakibatkan favoritisme dan pelayanan penuh terhadap agama-agama yang diakui. Pemahaman tentang pluralisme terbatas juga memicu penggolongan atau stratifikasi dalam pelayanan keagamaan. ${ }^{22}$ Enam agama resmi yang menjadi mayoritas di Indonesia mendapat keistimewaaan, berbeda dengan para agama leluhur yang lahir di bumi Indonesia seperti Sunda Wiwitan, Kaharingan, dan Parmalim. Selain itu bagi Najib, pluralisme terbatas membuat kriteria agama mengikuti agama resmi, seperti pengakuan terhadap adanya Tuhan yang Maha Esa, serta adanya nabi dan kitab suci. Jika agama-agama tersebut tidak mengikuti dan menyesuaikan secara teologis maka ia bukan dianggap sebagai agama atau diturunkan levelnya menjadi sekadar kepercayaan. ${ }^{23}$

20 Zainal Abidin Bagir dkk, "Limitations to Freedom of Religion or Belief in Indonesia: Norms and Practice," Religion and Human Rights 15, (2020): 39-56, diakses 10 Januari 2021, https://doi. org/10.1163/18710328-BJA10003.

${ }^{21}$ Julia Howell, “Muslims, the New Age and Marginal Religions in Indonesia: Changing Meanings Of Religious Pluralism," Sage Journals Social Compass, (2005): 473-494, diakses 26 Desember 2021, https:// doi.org/10.1177/0037768605058151.

22 Ahmad Najib Burhani, "Agama, Kultur (In)toleransi, dan Dilema Minoritas di Indonesia," dalam Orasi Pengukuhan Profesor Riset Bidang Agama dan Tradisi Keagamaan, (Jakarta: LIPI, 2020), 20.

23 Ibid., 21. 
Apa yang dijelaskan oleh Howell dan Burhani mengenai pluralisme terbatas sesuai dengan realitas. Realitas dari pluralisme terbatas adalah pengarusutamaan definisi agama yang membuat agama leluhur mengikuti definisi agama resmi, agar supaya mereka diakui sebagai agama. Jika tidak mengikuti, mereka tetap dipandang sebatas kepercayaan atau budaya yang ada di Indonesia. Menurut penulis ada tiga hal penting dalam melihat pembatasan ini. Pertama, pembatasan terhadap KBB yang pada dasarnya mengikuti agama resmi dan hal ini membuat agama-agama leluhur tereksklusi atau secara resmi telah ke luar dari jaminan hukum negara. Kedua, kebijakan KBB memunculkan pelayanan berbeda dalam beragama. Negara hanya melayani warga negara yang beridentitas agama resmi, sementara warga negara yang tidak mempunyai identitas tersebut tidak dapat dilayani. Ketiga, konsep KBB di Indonesia mengalami pelemahan dengan adanya pembatasan. Kesenjangan antara KBB yang dilegalkan di Indonesia dengan apa yang telah dirumuskan dalam DUHAM membuat munculnya pembatasan terhadap KBB di Indonesia itu sendiri

Pluralisme terbatas juga menunjukkan bahwa jika dari agama resmi lahir komunitas yang memiliki pemahaman berbeda dengan mayoritas pemeluk agama tersebut maka komunitas tersebut distigmatisasi dan dianggap telah menistakan agama. Komunitas keagamaan tersebut akan menghadapi situasi yang rumit dan diawasi oleh Badan Koordinasi Pengawas Aliran Kepercayaan dan Keagamaan (Bakor Pakem) yang merupakan lembaga resmi negara. Komunitas keagamaan dalam Islam yang banyak menghadapi hal ini adalah Ahmadiyah. Ahmadiyah dianggap sebagai aliran sesat dan mesti dibubarkan. ${ }^{24}$ Pluralisme terbatas menunjukkan permasalahan yang penting dalam fenomena pengelolaan KBB di Indonesia.

\section{Implikasi Pembatasan KBB di Indonesia}

Dengan analisis pluralisme terbatas, KBB di Indonesia bukan hanya membuat perbedaan antara agama resmi yang diakui dengan agama yang tidak resmi. Akan tetapi pluralisme terbatas menimbulkan implikasi pada tataran sosial. Implikasi ini berwujud pada diskriminasi dan intoleransi yang terus dihadapi oleh agama leluhur dan kelompok minoritas keagamaan.

\section{Diskriminasi}

Salah satu bagian dari implikasi tersebut adalah diskriminasi terhadap penganut agama leluhur. Adanya pengakuan enam agama yang

24 Ahmad Najib Burhani, "Fundamentalism and Religious dissent: the LPPI's mission to eradicate the Ahmadiyyah in Indonesia," Indonesia and the Malay World 44, no. 129 (2016): 145-164, diakses pada 30 Desember 2020, https://doi.org/10.1080/13639811.2015.1135610. 


\section{ROHIT MAHATIR MANESE}

memiliki definisi tertentu melahirkan diskriminasi terhadap agama leluhur. Tindakan diskriminasi terhadap agama leluhur telah menjadi budaya politik di Indonesia. Mereka terus diawasi oleh negara dan dicurigai oleh Bakor Pakem. Agama leluhur dianggap sebagai pengikut suatu budaya daripada disebut sebagai agama sehingga penyebutan yang sering melekat adalah penghayat kepercayaan. Dalam bentuk pelayanan publik mereka dipersulit dalam administrasi pernikahan karena harus mengikuti ketetapan yang dibuat dalam catatan administrasi negara. Hal ini membuat mereka tidak pernah menikah secara resmi. Salah satu dampak bagi pasangan yang berprofesi sebagai pegawai negeri tidak akan menerima tunjangan negara seperti tunjangan istri dan anak. Belum cukup sampai di situ, penganut agama leluhur dianggap sesat dan tidak memiliki bukti administrasi negara sehingga anak tersebut secara sosial dianggap sebagai anak yang lahir di luar nikah. Selanjutnya mereka rentan tertolak ketika mendaftar pada pendidikan formal karena tidak memiliki catatan administrasi negara seperti akta. ${ }^{25}$

Diskriminasi negara terhadap agama leluhur pada realitasnya dapat kita lihat pada Komunitas Sedulur Sikep di Kudus dan Pati. Komunitas Sedulur Sikep memeluk agama Adam yang dipercayai berasal dari para leluhur mereka. Banyak di antara mereka yang tidak memiliki Akta Perkawinan karena terganjal kolom agama yang kosong di KTP. ${ }^{26}$ Walaupun mereka tidak memedulikan hal itu, namun masalahnya berdampak panjang, seperti kesulitan akses pendidikan agama pada anak-anak mereka.

Kasus selanjutnya didapati pada penganut agama leluhur Sapta Darma di Candi Saptarengga, Yogyakarta. Mereka hidup dalam realitas diskriminatif. Bahkan sering ditolak warga ketika ingin menguburkan anggota keluarga yang meninggal, padahal penguburan tersebut dilakukan di tempat pemakaman umum milik pemerintah. Ketika mereka mengeluhkan hal ini, pemerintah tidak pernah mengambil sikap. ${ }^{27}$ Hal tersebut juga terjadi pada para penganut agama leluhur di Desa Trangkil, Kabupaten Pati, Jawa Tengah. Mereka sering ditolak warga ketika ingin melakukan penguburan di desa tersebut. Warga beralasan bahwa tempat pemakaman hanya

25 Nicola Colbran, "Realities and challenges in realising freedom of religion or belief in Indonesia," The International Journal of Human Rights 14, no. 5 (September 2010): 678-704, diakses 30 Desember 2021, https://doi.org/10.1080/13642980903155166

26 Sukirno, "Diskriminasi Pemenuhan Hak Sipil bagi Penganut Agama Lokal," Administrative Law $\mathcal{E}$ Governance Journal 1, (3 Agustus 2018): 231 - 239, diakses 10 Januari 2021, https://doi.org/10.14710/alj. v1i3.231-239.

27 Jayyidan Falakhi dan Rohit Mahatir Manese, "Pengikut Sapta Darma di Tengah Pluralitas Terbatas," Palita: Journal of Social Religion Research 5, no. 1 (2020): 49-64, diakses 5 Mei 2020, https://doi. org/10.24256/pal.v5i1.1273. 
untuk warga beragama Islam. ${ }^{28}$ Akhirnya hal itu membuat para penganut agama leluhur di sana melakukan konversi agama. Memang sejak tahun 2017 para penganut agama leluhur mulai mendapat titik terang ketika Mahkamah Konstitusi (MK) memutuskan bahwa kolom agama pada KTP mereka boleh diisi dengan penghayat kepercayaan. ${ }^{29}$ Akan tetapi putusan tersebut belum menjadi solusi atas diskriminasi yang terus mereka alami. Pada kenyataannya para penganut agama leluhur masih diperlakukan secara diskriminatif oleh aparat negara dalam mengurus KTP. Pada tahun 2019 penganut agama leluhur Budi Daya di Bandung masih sulit mengurus administrasi untuk keperluan pengobatan di rumah sakit. Mereka akan dilayani dengan syarat harus mengisi kolom agama dengan salah satu dari enam agama resmi yang diakui oleh negara. ${ }^{30}$

\section{Intoleransi}

Intoleransi berpotensi menjadi pelanggaran, kekerasan, dan penyulut konflik kemanusiaan. ${ }^{31}$ Dalam kasus pembatasan terhadap KBB di Indonesia penodaan agama menjadi topik yang sangat penting dan berpengaruh pada persepsi publik. Penodaan agama ini sering dikonstruksi mengacu pada agama resmi. Apabila ke luar dari konstruksi agama dominan maka kelompok keagamaan tersebut dipandang bukan bagian dari agama tersebut. Hal ini sering terjadi pada kelompok minoritas keagamaan, salah satunya adalah Ahmadiyah. Ahmadiyah merupakan kelompok muslim yang dilabeli telah menistakan Islam. Mereka dianggap mempraktikkan corak Islam yang berbeda dengan mayoritas muslim di Indonesia. Penistaan dan penodaan agama yang melekat pada Ahmadiyah menjadi motif dan penyulut bagi kelompok-kelompok ekstremis untuk melakukan tindakan intoleransi.

Kita dapat melihat fenomena intoleransi ini masif terjadi sejak era Reformasi. Pada 9 Juli tahun 2005 Ahmadiyah yang tengah melakukan pertemuan tahunan Jalsa Salana ${ }^{32}$, di kampus Mubarak, Bogor dipaksa

28 Sulaiman, "Problem Pelayanan terhadap Kelompok Penghayatan Kepercayaan di Pati, Jawa Tengah," Jurnal SMaRT Studi Masyarakat, Religi dan Tradisi 4, no. 2 (Desember 2018): 207-220, diakses 13 Januari 2021, https://doi.org/10.18784/smart.v4i2.649.

29 Kristian Erdianto, “MK: Kolom Agama di KTP dan KK Dapat Ditulis Penghayat Kepercayaan," Kompas, 7 November2017, diakses20Februari2021,https://nasional.kompas.com/read/2017/11/07/13020811/ mk-kolom-agama-di-ktp-dan-kk-dapat-ditulis-penghayat-kepercayaan?page=all.

30 Rio Tuasikal, "Penghayat Kepercayaan Masih Sulit Revisi Kolom Agama KTP," VOA Indonesia, 3 April 2019, diakses 13 Maret 2021, https://www.voaindonesia.com/a/penghayat-kepercayaan-masih-sulit-revisi-kolom-agama-ktp/4858804.html.

31 Alamsyah Djafar, Intoleransi Memahami Kebencian Atas Nama Agama (Jakarta: Elex Media Komputindo, 2018), 53.

32 Jalsa Salanah adalah kegiatan silaturahmi tahunan Ahmadiyah. Kegiatan ini diprakarsai langsung oleh pendiri Ahmadiyah Mirza Ghulam Ahmad. Kegiatan ini bertujuan agar umat muslim Ahmadiyah khususnya dan umat muslim yang lain berkumpul, untuk saling berinteraksi, meningkatkan moral, spiritual, dan terutama meningkatkan keimanan pada Tuhan. Jalsa Salanah utamanya adalah 
massa setempat menghentikan acara tersebut. ${ }^{33}$ Apabila para pengikut Ahmadiyah tidak menghentikan kegiatannya, maka aksi yang lebih tragis akan terjadi. Kelompok yang membubarkan kegiatan Jalsa Salanah tidak tanggung-tanggung akan melakukan tindakan penyerangan terhadap Ahmadiyah. Selanjutnya pada tahun 2011, tiga pengikut Ahmadiyah di Cikeusik, Banten, diserang dan dibunuh. Kejadian tersebut merupakan insiden anti-Ahmadiyah terparah di Indonesia. ${ }^{34}$ Padahal sejak beberapa tahun silam, HAM telah diundang-undangkan di Indonesia. Akan tetapi pelanggaran berat terhadap HAM berupa pembunuhan masih kerap terjadi dan menimpa kelompok minoritas, seperti Ahmadiyah.

Kasus intoleransi selanjutnya terjadi pada tahun 2015 di kelurahan Sri Menanti, Kabupaten Bangka. Di Sri Menanti Ahmadiyah sulit untuk mendapatkan KTP dan tempat tinggal. Hal itu berujung pada pengusiran yang dilakukan oleh Bupati Bangka pada tahun 2016. Bupati beralasan bahwa pengusiran dilakukan karena Ahmadiyah melakukan pembangkangan terhadap pemerintah. Bukan hanya pemerintah, kelompok masyarakat tertentu pun mengikuti langkah pemerintah agar Ahmadiyah dipaksa untuk angkat kaki dari Bangka. ${ }^{35}$ Intoleransi terhadap minoritas begitu masif di daerah-daerah Indonesia. Warga dan pemerintah saling berkait kelindan melakukan tindakan intoleran terhadap Ahmadiyah.

Kasus berikutnya terjadi pada tanggal 23 Mei 2016. Masjid Al-Kautsar milik Ahmadiyah di desa Purworejo, Kendal dirusak oleh puluhan orang. Perusakan masjid tersebut sebagai peringatan agar Ahmadiyah di Purworejo menghentikan aktivitas dakwahnya. Organisasi Majelis Mujahidin Indonesia (MMI) menjadi aktor dalam perusakan masjid Al-Kautsar. ${ }^{36}$ Bagi MMI Ahmadiyah adalah sesat dan telah menistakan Islam. Perusakan dan penyerangan terhadap tempat ibadah milik Ahmadiyah adalah salah satu cara untuk membela Islam.

kegiatan internasional untuk Ahmadiyah di seluruh dunia. Akan tetapi kegiatan ini juga sering dilakukan secara nasional oleh negara masing-masing. Indonesia adalah negara yang sering melakukan kegiatan ini.

33 Nina Mariani Noor, "Ahmadiyah, conflicts, and violence in contemporary Indonesia," Indonesian Journal of Islam and Muslim Societies (IJIMS) 3, no. 1 (Juni 2013): 1-30, diakses 5 Mei 2020, http://hdl.handle. net/20.500.12424/157174.

34 Julian Millie, "One Year after the Cikeusik Tragedy," Inside Indonesia, no. 107 (Januari-Maret 2012), diakses 5 Mei 2020, https://www.insideindonesia.org/one-year-after-the-cikeusik-tragedy.

35 Vindry Florentine, “Ini Kronologi Pengusiran Jemaat Ahmadiyah di Bangka,” Tempo, 9 Februari 2016, diakses 15 februari 2021, https://nasional.tempo.co/read/743223/ini-kronologi-pengusiran-jemaat-ahmadiyah-di-bangka.

36 Diah Wijayana, "Pelanggaran Hak Asasi Manusia Masyarakat Minoritas Jemaat Ahmadiyah (Studi Kasus: Perusakan Masjid Al-Kautsar Jemaat Ahamdiyah di desa Purworejo Kecamatan Ringinarum Kendal Tahun 2016)," Journal of Politic and Government Studies 8, no. 3 (Juli 2019): 91-100, diakses 15 Februari, https://ejournal3.undip.ac.id/index.php/jpgs/article/view/24061. 
Pada tahun 2018, persekusi terhadap Ahmadiyah di Lombok terjadi lagi. Kejadian ini terjadi pada tanggal $19 \mathrm{Mei}$, tepatnya di desa Gereneng, Lombok Timur. Sebanyak 7 rumah pengikut dirusak oleh sekelompok massa, serta diiringi dengan pengusiran Ahmadiyah dari desa tersebut. ${ }^{37}$ Kelompok-kelompok yang sering melakukan intoleransi merasa terganggu atas kehadiran Ahmadiyah. Bagi mereka Ahmadiyah telah menodai Islam dan telah tersesat pada jalan yang salah. Melakukan tindakan apapun termasuk penyerangan adalah sebuah kewajaran.

Pelanggaran terhadap KBB, sesuai dengan laporan yang ada, tidak pernah turun dari angka ratusan. Kita akan menemukannya pada datadata yang diberikan oleh lembaga-lembaga yang berfokus memantau perkembangan pelanggaran KBB di Indonesia. Sesuai dengan data yang diberikan oleh Wahid Institute mengenai peristiwa pelanggaran terhadap KBB dalam catatan 10 tahun terakhir sejak 2009-2015 diantaranya adalah; 2009 (121 kasus), 2010 (216 kasus), 2011 (267 kasus), 2012 (274 kasus), 2013 (245 kasus), 2014 (158 kasus), 2015 (190 kasus).

Setara Institute juga memantau pelanggaran atas KBB dan menunjukkan; tahun 2009 (200 kasus), 2010 (216 kasus), 2011 (244 kasus), 2012 (264 kasus), 2013 (222 kasus), 2014 (134 kasus), 2015 (197 kasus). ${ }^{38}$ Di tahun-tahun berikutnya, catatan terhadap peristiwa pelanggaran KBB masih tinggi, bahkan tidak pernah turun dari ratusan peristiwa. Pada tahun 2016, Setara Institute mencatat telah terjadi 206 pelanggaran KBB di seluruh Indonesia. Jawa Barat menjadi daerah terbanyak melakukan pelanggaran. ${ }^{39}$ Pada tahun 2017, menurut catatan Setara Institute telah terjadi 151 peristiwa pelanggaran KBB. Pelanggaran ini banyak menimpa kelompok minoritas di Indonesia. ${ }^{40}$ Sedangkan pada tahun 2018 Setara Institute mencatat bahwa telah terjadi 160 peristiwa pelanggaran KBB. Jawa Barat merupakan provinsi tertinggi pelanggaran KBB dengan jumlah 24 peristiwa. Sementara DKI menempati posisi kedua dengan 23 peristiwa pelanggaran KBB. ${ }^{41} \mathrm{Di}$ tahun

37 Abdul Jamil Wahab \&Fakhruddin, "Menakar Efektivitas SKB Tentang Ahmadiyah dan faktor Penyebabnya: Studi Kasus Konflik Ahmadiyah di Desa Gereneng Lombok Timur," Jurnal Harmoni 18, no. 1 (2019): 443-459, diakses 15 februari 2021, https://doi.org/10.32488/harmoni.v18i1.

38 Irsyad Rafsadi, "Catatan Satu Dasawarsa Pengukuran dan Pemantauan, dalam Kebebasan Beragama di Indonesia," dalam Toleransi dan Terorisme Riset dan Kebijakan Agama di Indonesia, ed. Ihsan Ali-Fauzi, Zainal Abidin Bagir, \& Irsyad Rafsadi (Jakarta: Pusad Paramadina, 2017), 108.

39 Heldania Ultri Lubis, “SETARA: Pelanggaran Kebebasan Beragama Tertinggi Ada di Jabar," Detik, 29 Januari 2017, diakses 20 Februari 2021, https://news.detik.com/berita/d-3408393/setara-pelanggarankebebasan-beragama-tertinggi-ada-di-jabar.

40 Moh. Nadlir, “Tahun 2017: Pelanggaran Kebebasan Beragama Terbanyak di Jawa Barat,” Kompas, 15 Januari 2018, diakses 20 Februari 2021, https://nasional.kompas.com/read/2018/01/15/18233341/ tahun-2017-pelanggaran-kebebasan-beragama-terbanyak-di-jawa-barat.

${ }_{41}$ Haili dkk, Melawan Intoleransi di Tahun Politik, Kondisi Kebebasan Beragama/Berkeyakinan di Indonesia Tahun 2018, (Jakarta: Pustaka Masyarakat Setara, 2018), 29. 
yang sama Wahid Institute juga mengeluarkan laporan bahwa telah terjadi 160 peristiwa pelanggaran KBB dengan 202 tindakan pelanggaran di 25 provinsi Indonesia. ${ }^{42}$

Sementara pada tahun 2019 merujuk pada pemantauan KBB yang dilakukan oleh Imparsial (The Indonesian Human Rights Monitor) terdapat 31 kasus intoleransi atau pelanggaran KBB di 15 provinsi di Indonesia. ${ }^{43}$ Tahun 2020 juga demikan, intoleransi masih menjadi masalah yang nyata terhadap pelanggaran KBB di Indonesia. Berdasarkan riset tahun 2020 dari Pusat Pengkajian Islam dan Masyarakat (PPIM) UIN Jakarta mencatat bahwa 30,16 persen mahasiswa Indonesia memiliki sikap beragama yang rendah atau intoleran. Riset yang dilakukan pada 34 provinsi ini melibatkan 79 perguruan tinggi, 673 dosen dan 2.866 Mahasiswa. ${ }^{44}$

Kebijakan penodaan dan penistaan agama menjadi ancaman nyata bagi kehidupan KBB di Indonesia. Akibat dari tafsiran tersebut kelompok minoritas di Indonesia sulit untuk menjalankan agamanya. Mereka harus patuh pada agama dominan dan para pemeluknya yang memiliki mental mayoritas. Pembatasan KBB berdampak panjang bagi kehidupan keagamaan di Indonesia yang secara nyata mengakibatkan konflik atas nama agama. Pembatasan KBB yang dilakukan negara menghasilkan pembelengguan atas hak asasi warga negara. Pembelengguan tersebut membuat mereka sulit untuk beragama dan berkeyakinan secara damai, apalagi mempraktikkannya di ranah publik. Selain itu pembatasan terhadap KBB menjadi penyulut bagi kelompok-kelompok tertentu untuk berbuat tindakan intoleran hingga mewujud pada penganiayaan dan pembunuhan. Pelanggaran terhadap KBB masih akan terus berlanjut, jika tidak ada sikap transformatif dan konstruktif dari negara dalam menafsirkan KBB itu sendiri.

\section{Kesimpulan}

Dalam konteks global KBB dideklarasikan oleh bangsa-bangsa yang termaktub pada DUHAM tahun 1948 serta ICCPR tahun 1966. Dalam DUHAM pasal 18 dijelaskan bahwa setiap orang atau individu berhak untuk berpikir, bernurani serta beragama. Mengikuti langkah internasional, KBB

42 Alamsyah Djafar, Rekomendasi Kebijakan Perlunya Langkah Terobosan Pemerintah, Satu Dekade Pemantauan Kemerdekaan Beragama dan Berkeyakinan (KBB) Wahid Foundation, (Jakarta: Wahid Foundation, 2020), 1.

43 “Imparsial: "Negara Harus Hadir dalam Melindungi Kebebasan Beragama atau Berkeyakinan," Imparsial The Human Rights Monitor, 17 November 2019, diakses 13 Maret 2021, https://imparsial.org/ hari-toleransi-internasional-negara-harus-hadir-dalam-melindungi-kebebasan-beragama-atau-berkeyakinan/.

44 Deti Mega Purnamasari, “Riset PPIM UIN Jakarta: 30,16 Persen Mahasiswa Indonesia Intoleran," Kompas, 2 Maret 2021, diakses 13 Maret 2021, https://nasional.kompas.com/read/2021/03/02/13353621/ riset-ppim-uin-jakarta-3016-persen-mahasiswa-indonesia-intoleran?page=all. 
merupakan hak paling fundamental. Negara bertanggung jawab melindungi dan menjamin KBB warga negaranya. Negara bahkan tidak dapat membatasi ataupun mencabut hak KBB tersebut meskipun negara berada dalam kondisi darurat.

Sementara setelah reformasi, Indonesia mulai melegalkan KBB walaupun di sisi yang lain membatasi KBB itu sendiri. Pembatasan KBB di Indonesia disebabkan karena nilai-nilai agama serta definisi agama yang mengacu pada aturan penodaan dan pencegahan penyalahgunaan agama. Hal itu membuat KBB di Indonesia bertolak belakang dengan KBB yang menjadi konsensus dalam DUHAM serta ICCPR. Di samping itu, KBB di Indonesia membuat agama leluhur dan kelompok minoritas harus mengikuti agama yang telah diresmikan oleh negara. Jika ingin diakui sebagai agama, mereka harus menyesuaikan dengan aturan yang mengacu pada definisi agama resmi. Sikap negara sangat berbeda dalam hal pelayanan keagamaan antara pemeluk agama resmi dengan agama leluhur.

Pada aras sosial, pembatasan KBB melahirkan diskriminasi terhadap agama-agama yang lahir dari rahim negara itu sendiri yang selanjutnya menjadi penyulut intoleransi terhadap kelompok minoritas keagamaan di Indonesia. Kita perlu ke luar dari akar masalah dengan melakukan pengkajian kembali rumusan KBB yang ada di Indonesia khususnya hal pembatasan KBB itu sendiri. ${ }^{45}$

Penulis juga membuka ruang bagi penelitian-penelitian selanjutnya yang tetap berfokus pada masalah kebebasan beragama dan berkeyakinan di Indonesia: Pertama, dalam penelitian ini penulis hanya melampirkan data pelanggaran kebebasan beragama dan berkeyakinan dari lembaga pemantauan dalam negeri. Alangkah baiknya untuk penelitian selanjutnya menampilkan data atau indeks pelanggaran KBB dari pemantauan LSM luar negeri. Kedua, dalam penelitian ini penulis tidak menjelaskan faktor penyebab naik dan turunnya kasus pelanggaran KBB di Indonesia. Kedua hal tersebut diharapkan dapat memperkaya informasi tentang perkembangan kajian KBB di Indonesia.

\section{Daftar Pustaka}

Abidin, Zainal, dkk. "Limitations to Freedom of Religion or Belief in Indonesia: Norms and Practice." Religion and Human Rights 15 (2020): 39-56. Diakses 10 Januari 2021. https://doi.org/10.1163/18710328-BJA10003. Bagir Abidin, Zainal, dkk. "Membatasi Tanpa Melanggar, Hak Kebebasan Beragama atau Berkeyakinan." CRCS UGM (2019). 
Budiwanti, Erni, "Pluralism Collapses: A Study of the Jama'ah Ahmadiyah Indonesia and its Persecution" Asia Research Institute, National University of Singapore ARI Working Paper no. 117 (Juni 2009): 1-26. https://papers.ssrn.com/sol3/papers.cfm?abstract_id=1645144. Burhani Najib, Ahmad. "Agama, Kultur (In)toleransi, dan Dilema Minoritas di Indonesia." Dalam Orasi Pengukuhan Profesor Riset Bidang Agama dan Tradisi Keagamaan. Jakarta: LIPI, 2020.

Burhani Najib, Ahmad. "Fundamentalism and Religious dissent: the LPPI's mission to eradicate the Ahmadiyyah in Indonesia." Indonesia and the Malay World 16 (2020): 189-223. Diakses 30 Desember 2020. https:// doi.org/10.1080/13639811.2015.1135610.

Burhani Najib, Ahmad. "Fundamentalism and Religious dissent: the LPPI's mission to eradicate the Ahmadiyyah in Indonesia." Indonesia and the Malay World 44, no. 129 (201620): 145-164. Diakses 30 Desember 2020. https://doi.org/10.1080/13639811.2015.1135610.

Colbran, Nicola. "Realities and challenges in realising freedom of religion or belief in Indonesia." The London, International Journal of Human Rights 14, no. 5 (September 2010): 678-704. Diakses 30 Desember 2021. https://doi.org/10.1080/13642980903155166.

Djafar, Alamsyah. Intoleransi Memahami Kebencian Atas Nama Agama. Jakarta: Elex Media Komputindo, 2018.

Djafar, Alamsyah. Rekomendasi Kebijakan Perlunya Langkah Terobosan Pemerintah, Satu Dekade Pemantauan Kemerdekaan Beragama dan Berkeyakinan (KBB) Wahid Foundation. Jakarta: Wahid Foundation, 2020.

Erdianto, Kristian. “MK: Kolom Agama di KTP dan KK Dapat Ditulis "Penghayat Kepercayaan"."Kompas. 7 November 2017. Diakses 20 Februari 2021. https://nasional.kompas.com/ read/2017/11/07/13020811/mk-kolom-agama-di-ktp-dan-kk-dapat-ditulis-penghayat-kepercayaan?page=all.

Faiq, Tobroni. "Pembedaan Beragama dan Penodaan Agama (Studi Putusan No 69/Pid. B/2012/PN. Spg). "al-Jinâyah: Jurnal Hukum Pidana Islam 5, no. 2 (Desember 2019): 489-501. https://doi.org/10.15642/ aj.2019.5.2.489-510.

Fauzi Ali, Ishan, dkk. “Kajian tentang Kebebasan Beragama dan Berkeyakinan dan Implikasinya untuk Kebijakan." Dalam Kebebasan, Toleransi dan Terorisme Riset dan Kebijakan Agama di Indonesia dkk. Jakarta: PUSAD, 2017.

Florentine, Vindry. "Ini Kronologi Pengusiran Jemaat Ahmadiyah di Bangka." Tempo. 9 Februari 2016. Diakses 5 Mei 2020. https://www. 
insideindonesia.org/one-year-after-the-cikeusik-tragedy.

Haili, dkk, Melawan Intoleransi di Tahun Politik, Kondisi Kebebasan Beragama/Bekeyakinan di Indonesia Tahun 2018. Jakarta: Pustaka Masyarakat Setara, 2018.

Hasanuddin, Iqbal. “Hak atas Kebebasan Beragama/Berkeyakinan: Sebuah Upaya Pendasaran Filosofis." Societas Dei 4, no. 1 (April 2018): 96 112. Diakses 15 Februari 2021. http:// doi.org/10.33550/sd.v4i1.44.

Howell, Julia. "Muslims, The New Age and Marginal Religions in Indonesia: Changing Meanings Of Religious Pluralism." Jurnal Sagepub London: Social Compass. (2005): 474-495. Diakses 26 Desember 2021. https:// doi.org/10.1177/0037768605058151.

Imparsial. "Negara Harus Hadir dalam Melindungi Kebebasan Beragama atau Berkeyakinan." Imparsial: The Human Rights Monitor, 17 November 2019. Diakses 13 Maret 2021. https://imparsial.org/ hari-toleransi-internasional-negara-harus-hadir-dalam-melindungikebebasan-beragama-atau-berkeyakinan/.

Jayyidan, Falakhi, Manese Mahatir Rohit. "Pengikut Sapta Darma di Tengah Pluralitas Terbatas." Palita: Journal of Social Religion Research 5 (April 2020). Diakses 5 Mei 2020. https://doi.org/10.24256/pal.v5i1.1273.

Lubis Ultri, Heldania. "SETARA: Pelanggaran Kebebasan Beragama Tertinggi Ada di Jabar." Detik, 29 Januari 2017. Diakses 20 Februari 2021. https://news.detik.com/berita/d-3408393/ setara-pelanggaran-kebebasan-beragama-tertinggi-ada-di-jabar.

Majelis Umum PBB, Deklarasi Universal Hak-Hak Asasi Manusia. Diterima dan diumumkan oleh majelis Umum melalui resolusi 217 A (III) Paris: 217 A, 1948, 1-6. Diakses 2 April 2021. https://www.komnasham.go.id/ files/1475231326-deklarasi-universal-hak-asasi--\$R48R63.pdf.

Maria, Grant J, dan Bootht Andrew. "A typology of reviews: an analysis of 14 review types and associated methodologies." Journal compilation, Health Information and Libraries Journal, (2009): 91-108. DOI: 10.1111/j.1471-1842.2009.00848.x.

Mariani Noor, Nina. "Ahmadiyah, conflicts, and violence in contemporary Indonesia." Indonesian Journal of Islam and Muslim Societies (IJIMS) 3, no. 1 (June 2013): 1-30. Diakses 5 Mei 2020. http://hdl.handle. net/20.500.12424/157174.

Marizal, Lutfy M., “Ini 11 Kasus Pelanggaran Kebebasan Beragama Berkeyakinan3Bulan Terakhir." Kompas, 1 Juli 2016. Diakses 24 Februari 2021, https://nasional.kompas.com/read/2016/07/01/05050071/Ini.11. Kasus.Pelanggaran.Kebebasan.Beragama.atau.Berkeyakinan.3.Bulan. Terakhir?page=all. 
Mega Purnamasari, Deti. “Riset PPIM UIN Jakarta: 30,16 Persen Mahasiswa Indonesia Intoleran." Kompas, 2 Maret 2021. Diakses 13 Maret 2021. https://nasional.kompas.com/read/2021/03/02/13353621/ riset-ppim-uin-jakarta-3016-persen-mahasiswa-indonesia-intoleran?page=all.

Millie, Julian. “One Year after the Cikeusik Tragedy." Inside Indonesia no. 107 (Januari-Maret 2012). Diakses 5 Mei 2020. https://www.insideindonesia.org/one-year-after-the-cikeusik-tragedy.

Nadlir, Moh. "Tahun 2017: Pelanggaran Kebebasan Beragama Terbanyak di Jawa Barat." Kompas. 15 Januari 2018. Diakses 20 Februari 2021. https:// nasional.kompas.com/read/2018/01/15/18233341/tahun-2017-pelanggaran-kebebasan-beragama-terbanyak-di-jawa-barat.

Puneri Selim, Delmus. "Kerukunan Umat Beragama Vs Kebebasan Beragama di Indonesia." Jurnal Potret Pemikiran 21, no. 2, (Juli -Desember 2017): 15-35. Diakses 21 Desember 2020. http://dx.doi.org/10.30984/ pp.v21i2.741.

Raco, J. R. Metode Penelitian Kualitatif Jenis, Karakteristik, dan Keunggulannya. Jakarta: Grasindo, 2010.

Rafsadi, Irsyad. "Catatan Satu Dasawarsa Pengukuran dan Pemantauan, dalam Kebebasan Beragama di Indonesia." Dalam Toleransi dan Terorisme Riset dan Kebijakan Agama di Indonesia, ed. Ihsan Ali-Fauzi, Zainal Abidin Bagir, \& Irsyad Rafsadi. Jakarta: Pusad Paramadina, 2017.

Republik Indonesia, Undang-Undang Dasar Negara Republik Indonesia Tahun 1945, pasal 28. Jakarta: Pemerintah Republik Indonesia, 2002. Diakses 2 April 2002. https://luk.staff.ugm.ac.id/atur/UUD1945.pdf. Republik Indonesia. Undang-Undang Republik Indonesia Nomor 12 Tahun 2005 Tentang Pengesahan Internartional Covenant On Civil And Political Rights: Kovenan Internasional Tentang Hak-Hak Sipil dan Politik. Lembaran Negara Republik Indonesia nomor 119. Jakarta, Pemerintah Republik Indonesia, 2005. Diakses 20 Maret 2021. https:// www.dpr.go.id/doksetjen/dokumen/-Regulasi-UU-No.-12-Tahun2005-Tentang-Pengesahan-Kovenan-Internasional-Tentang-Hak-HakSipil-dan-Politik-1552380410.pdf.

Situmorang, Victoria H. "Kebebasan Beragama Sebagai Bagian dari Hak Asasi Manusia." Jurnal Penelitian HAM 10, no. 1 (Juli 2019): 57-67. Diakses 13 Januari 2021. http://dx.doi.org/10.30641/ham.2019.10.5767., https://core.ac.uk/reader/268381800.

Sukirno. "Diskriminasi Pemenuhan Hak sipil Bagi Penganut Agama Lokal." Administrative Law \& Governance Journal 1, (3 Agustus 
2018): 231-239. Diakses 10 Januari 2021. https://doi.org/10.14710/alj. v1i3.231-239.

Sulaiman, "Problem Pelayanan terhadap Kelompok Penghayatan Kepercayaan di Pati, Jawa Tengah." Jurnal SMaRT Studi Masyarakat, Religi dan Tradisi 4, no. 2 (Desember 2018): 207-220. Diakses 13 Januari 2021. https://doi.org/10.18784/smart.v4i2.649.

Tore, Lidhlom. "Philosophical and Religious Justifications of Freedom of Religion or Belief." In Tore Lindholm, W. Cole Durham, Jr., Bahia G. Tahzib-Lie, ed. Facilitating Freedom of Religion or Belief: A Deskbook. Springer: 2004.

Tuasikal, Rio. "Penghayat Kepercayaan Masih Sulit Revisi Kolom Agama KTP." VOA Indonesia. 3 April 2019. Diakses 13 Maret 2021. https:// www.voaindonesia.com/a/penghayat-kepercayaan-masih-sulit-revisi-kolom-agama-ktp/4858804.html.

Wahab Jamil, Abdul dan Fakhruddin. "Menakar Efektivitas SKB Tentang Ahmadiyah dan faktor Penyebabnya: Studi Kasus Konflik Ahmadiyah di Desa Gereneng Lombok Timur." Jurnal Multikultural \& Multireligius 17 (2019): 443-459. Diakses 15 Februari 2021. https:// doi.org/10.32488/harmoni.v18i1.356.

Wijayana, Diah. "Pelanggaran Hak Asasi Manusia Masyarakat Minoritas Jemaat Ahmadiyah (Studi Kasus: Perusakan Masjid Al-Kautsar Jemaat Ahamdiyah di Desa Purworejo Kecamatan Ringinarum Kendal Tahun 2016)." Journal of Politic and Government Studies 8, no. 3 (Juli 2019): 91-100. Diakses 15 Februari. https://ejournal3.undip.ac.id/index.php/ jpgs/article/view/24061. 